\title{
ECONOMIC STUDY OF THE CULTIVATION OF KALE, CORIANDER, LETTUCE, AND CHIVES IN INTERCROPPING
}

\author{
ESTUDO ECONÔMICO DO CULTIVO DA COUVE, COENTRO, ALFACE E \\ CEBOLINHA EM CONSÓRCIO
}

\author{
Rodolfo Rodrigo de Almeida LACERDA ${ }^{1}$; Odair Honorato de OLIVEIRA ${ }^{2}$; \\ Caciana Cavalcanti COSTA ${ }^{2}$; Ivislanne de Sousa Queiroga LACERDA ${ }^{2}$; \\ José Magno Queiroz LUZ ${ }^{3}$, Anielson dos Santos SOUZA \\ Roberto Cleiton Fernandes de QUEIROGA ${ }^{2}$; Laíza Gomes de PAIVA ${ }^{1}$ \\ 1. Universidade Federal do Semi-árido-UFERSA, Mossoró, RN; 2. Universidade Federal de Campina Grande, Campus Pombal, PR, \\ Brasi. "ccavalcantic@gmail.com; 3. Universidade Federal de Uberlândia-UFU, Uberlândia, MG, Brasil.
}

\begin{abstract}
Intercropping of vegetables in a poorly planned manner may not achieve the expected economic results, as it is an activity that requires a great technical and administrative capacity of the producer. This study aimed to analyze the economic feasibility of intercropping kale with coriander, lettuce, and chives in relation to monocultures. The experiment was conducted in the Center for Agri-food Science and Technology, Federal University of Campina Grande, in the municipality of Pombal, PB in the period from June 2014 to July 2015. Eleven treatments were tested: four polycultures, three bicultives, and four monocultures, in randomized blocks, with four replications. The productivity, total operating costs (TOC), gross and net revenue, rate of return, profitability index, and efficient land use were evaluated. The TOC values of intercropping were calculated with the prices of July 2015. In all the systems studied, the largest participation was referring to the cost hand of labor. The highest gross and net revenues were observed in the kale with lettuce in bicultive, the rate of return and profitability index was higher on lettuce in monoculture. Despite the increase in the TOCs of the intercropping in relation to the monocultures, the intercropping proved to be economically viable in terms of efficient land use, reaching values indicating a land-use efficiency of up to $50 \%$ more in polycultures and bicultives.
\end{abstract}

KEYWORDS: Allium schoenoprasum L. Brassica oleracea var. acephala DC. Coriandrum sativum L. Lactuca sativa L. Polyculture.

\section{INTRODUCTION}

Kale (Brassica oleracea L. var. acephala DC.) occupies a prominent place in the production of these vegetables in Brazil, it is one of the oldest forms of the Brassicaceae family. The Brassica genus stands out in terms of its nutraceutical properties, production volume, and satisfactory economic return. Its leaves have a high concentration of water and low content of lipids, carbohydrates, and caloric properties, causing the consumption of this vegetable to increase, in search of healthy habits and health promotion (NOVO et al., 2010; AZEVEDO et al., 2014)

Given the importance and peculiarities of the production of vegetables, cultivation systems to obtain greater economic stability have been sought. Intercropping cultivation emerges as a strategy for maximizing production in cultivated areas to ensure maximum return through greater productivity, economic stability, as well as more efficient use of available resources such as soil, water, light, and nutrients (SEDIYAMA; SANTOS; LIMA, 2014).

However, the success of the intercropping system is directly related to the management adopted due to the factors involved in the production process, such as, for example, crop selection (BATISTA et al., 2016; BEZERRA NETO et al., 2012; OLIVEIRA et al., 2015).

Researches have been carried out testing the behavior of vegetable cultivars in intercropped systems, demonstrating their adaptation to the cultivation system. In the kale crop, the intercropping system has shown promise in association with other vegetables, such as garlic, onion (Allium sativum L.), chives (Allium schoenoprasum L.), parsley (Petroselinum crispum Mill.) and potato (Solanum tuberosum L.).

However, the recommendation of a production system goes through, necessarily, per its economic evaluation. Because economic analysis allows producers to make decisions about the best option for adopting technologies (CARVALHO et 
Economic study...

al. 2016). Highlight the need of conducting an economic analysis of the intercropped, since the vegetables present variations of price and the cost of production during the whole year (REZENDE et al., 2010).

The confirmation of the agronomic viability of the intercropped is observed in its economic yields when comparing its costs of production with those relative to the monocultures. It is also important to emphasize that in the intercropping there is a reduction in the expenses with the preparation of the land in the pre-implantation of the crops and with depreciation, in comparison to the sum of the monocultures of the two cultures. Thus, in the intercropping system, there is a shared cost of production among crops involved, reducing the final value (CECÍLIO FILHO et al., 2010; PAIVA et al., 2016; LACERDA et al., 2017).

The economic analysis for the culture of lettuce intercropped with coriander showed that when the fertilizer used was manure, the production cost was reduced when compared to that of lettuce in monoculture (LACERDA et al., 2017). In a study about the economic viability of lettuce in intercropping with arugula was observed that the item with the greatest impact on the cost of operations was the common labor, specifically the activities related to the harvest and post-harvest that consumed around 71 and 69, 6\%, respectively (NASCIMENTO et al., 2018).

However, there are few studies on the economic viability of intercropping systems, mainly involving the kale, and that increasing vegetable species diversity in a poorly planned manner may not achieve the expected economic and production
LACERDA, R. R. A. et al.

results. Such factors can do either with what the greatest volume of vegetables produced per unit area, do not reflect positively in higher profitability of the cultivation system, thus, the present work had the objective of analyzing economic viability of intercropping kale systems with coriander, lettuce, and chives in relation to monocultures.

\section{MATERIAL AND METHODS}

The experiment was carried out in the period from June 2014 to July 2015, at the Center for Agri-food Science and Technology, Federal University of Campina Grande, in the municipality of Pombal $\left(06^{\circ} 46^{\prime} 12^{\prime \prime} \mathrm{S}, 37^{\circ} 47^{\prime} 56^{\prime \prime} \mathrm{W}\right.$; at an altitude of $185 \mathrm{~m}$ ).

According to the classification of Köppen adapted to Brazil, the predominant climate in the region is BSh, hot and dry semi-arid with summerautumn rains, an average rainfall of $750 \mathrm{~mm}$ and average evaporation of $2,000 \mathrm{~mm}$. The soil of the area was classified as Luvissolo with sandy loam texture, whose chemical characteristics were: $\mathrm{pH}$ $\left(\mathrm{CaCl}_{2}\right)=8.0 ; \mathrm{P}$ (resin) $=675 \mathrm{mg} \mathrm{dm}^{-3} ; \mathrm{K}=0.68$ cmolc $\mathrm{dm}^{-3} ; \mathrm{Ca}=7.6 \mathrm{cmolc} \mathrm{dm}^{-3} ; \mathrm{Mg}=3.8 \mathrm{cmol}$ $\mathrm{dm}^{-3}$ and $\mathrm{V}=72 \%$.

The experimental design was in randomized blocks with four replications. Corresponding to 11 (eleven) treatments, composed by the combination of cultures: of the main culture of kale (Brassica oleracea var. acephala DC.) with coriander (Coriandrum sativum L.) 'verdão', lettuce (Lactuca sativa L.) 'Elba' and chives 'todo ano', corresponding to four polycultures, three bicultives, and four monocultures according to table 1.

Table 1. Cultivation system (treatments) for kale (main culture), coriander, lettuce, and chives in polyculture, bicultive, and monoculture.

\begin{tabular}{|c|c|}
\hline Treatments & Cultivation Systems \\
\hline T1 & Monoculture of kale (K) \\
\hline $\mathrm{T} 2$ & Monoculture of coriander (Co) \\
\hline T3 & Monoculture of lettuce (L) \\
\hline $\mathrm{T} 4$ & Monocultivo of chives ( $\mathrm{Ch}$ ) \\
\hline T5 & Bicultive of kale and coriander ( $\mathrm{K}$ e $\mathrm{Co})$ \\
\hline T6 & Bicultive of kale and lettuce (K e L) \\
\hline $\mathrm{T} 7$ & Bicultive of kale and chives ( $\mathrm{K}$ e $\mathrm{Ch}$ ) \\
\hline $\mathrm{T} 8$ & Polyculture of kale, coriander, lettuce, and chives (K, Co, L e Ch) \\
\hline T9 & Polyculture of kale, coriander, and lettuce $(\mathrm{K}, \mathrm{Co}$ e $\mathrm{L})$ \\
\hline $\mathrm{T} 10$ & Polyculture of kale, lettuce, and chives (K, L e Ch) \\
\hline $\mathrm{T} 11$ & Polyculture of kale, coriander, and chives (H, Co e Ch) \\
\hline
\end{tabular}

The plots measured $1.20 \mathrm{~m}$ wide by $2.5 \mathrm{~m}$. The line spacing of the cultures occurred according to the system used. In the monoculture was $1.00 \mathrm{~m}$ for kale, $0.30 \mathrm{~m}$ for one lettuce and $0.25 \mathrm{~m}$ for coriander and chives, and between plants was 0.60 $\mathrm{m}$ for kale, $0.25 \mathrm{~m}$ for lettuce, and $0.15 \mathrm{~m}$ for 
chives. For the cultures of lettuce, coriander, and chives in intercropped of one of these with kale, these were implanted in four growing lines. In intercropping with more than two crops, their populations were halved. Kale, lettuce, and chives seedlings were sowing in trays polyethylene with 128,288 , and 288 cells, respectively. In the case of coriander, sowing occurred carried out directly in the planting furrow at the time of transplanting other crops.

In relation to the cost of production, activities aimed at the production of seedlings constituted the and washing operations of trays, preparation of the substrate, assembly of beds, and realization of manual seeding. Prior to the lifting of the beds, a plowing, and two tillage were performed, using a three-disc 26 "plow and a grid of 24" 18 "discs. The soil cleansing was carried out with herbicide (Phosphonomethyl group).

The fertilization was done based on soil analysis and following the recommendation of the culture (CAVALCANTI et al., 2008), for the intercropping was carried out the fertilization of planting with the prescription for kale (CAVALCANTI et al., 2008). Was used $40 \mathrm{~kg} \mathrm{ha}^{-1}$ of $\mathrm{N}$ (urea); $40 \mathrm{~kg} \mathrm{ha}^{-1}$ of $\mathrm{P}_{2} \mathrm{O}_{5}$ and $40 \mathrm{~kg} \mathrm{ha}^{-1}$ of $\mathrm{K}_{2} \mathrm{O}$. Coverage fertilizations were performed separately for each crop, regardless of the cropping system. That is, for kale, lettuce, and chives the fertilization was divided into three stages, already for coriander, only two stages.

The irrigation was done employing microsprinklers, with a flow of $40 \mathrm{~L} \mathrm{~h}^{-1}$ and radial reach of $2.5 \mathrm{~m}$, distributed with the equidistance of 1.50 $\mathrm{m}$, the system was constituted by moto pump of 2.0 $\mathrm{CV}$ of power and tubes of the mainline of an inch in diameter and those of the $1 / 2$ inch sideline. In the estimation of common manpower was used the time of 10 minutes, to turn on and off the system, in addition to repairs.

During the conduction of the experiment, weed control with manual weeding was carried out. Due to the influence of each cultivation system on germination and weed growth, the weeding in the treatments was in differentiated numbers.

Regarding the phytosanitary treatments, the insecticide of the Neonicotinoid group was also used, provided from the 5 days after the installation of the experiment in 22-day intervals, considering the indication for the main culture and the control of the whitefly (Bemisia tabaci Genn.).

The harvests occurred from 35 days after transplanting (DAT), for coriander and lettuce at one time and for kale and chives were fulfilled five harvests. In the postharvest, the washing, classification, and packaging of the products were carried out.

In order to calculate the yield $\left(\mathrm{kg} \mathrm{ha}^{-1}\right)$ of the crops, the production of fresh mass was used in the effective area of the plot $\left(3.00 \mathrm{~m}^{2}\right)$ and the plant population, according to the spacing of each treatment; then productivity was estimated at 1 hectare considering $75 \%\left(7,500 \mathrm{~m}^{2}\right)$ of the effective area as useful.

The land-use efficiency (LUE) index was calculated according to being: $\mathrm{LUE}=(\mathrm{Yab} / \mathrm{Yaa})+$ (Yba / Ybb). Where, Yab: is the production of the crop "a" in an intercropping with culture "b"; Yba; is the production of culture " $b$ " in intercropping with culture "a"; Yaa: production of the crop "a" in monoculture, and Ybb: the production of " $b$ " crop in monoculture (MEAD; WILLEY, 1980),

The structure of the cost of production used was the operational cost of production that takes into account the actual disbursements accomplished made by the producer (MATSUNAGA et al., 1976). For soil preparation operations and input applications, the technical coefficients were used (BRANCALIÃO, 1999). The other coefficients were obtained during the conduction of the experiment. The unit values of each item, referring to July 2015, were calculated as follows:

Cost hand labor (MO) was calculated from the monthly salary obtained from the Union of Rural Workers of Pombal, this amount being $\mathrm{R} \$ 810.00$ for common labor (manual) and $\mathrm{R} \$ 891.00$ specialized (tractor). Salary values for a workload of 200 hours per month. In this way, the determined hour-costs were R\$ 4.05 and $\mathrm{R} \$ 4.46$ for common and specialized labor, respectively.

For the calculation of the cost-hour of the machine (HM) tractor, it was considered: $\mathrm{HM}=\mathrm{i}+$ $\mathrm{g}+\mathrm{r}+\mathrm{m}$. Where: insurance (i), garage $(\mathrm{g})$, and repairs (r) were, respectively, $0.75 \%, 1 \%$, and $10 \%$, per year, of the value of the machine, considering 1,000 hours of machine use per year, in addition to maintenance spending (m), which is about $20 \%$ of the total with fuel in operations (BRANCALIÂO, 1999). In the cost-hour (HO) operations, we used the sum of the costs with tractor, implements, and fuel spent in each operation.

The prices of inputs, materials, and products were obtained in the database of the Institute of Agricultural Economics, for some equipment and inputs were obtained in the commerce of the region of Pombal-PB. The sales prices per kilogram of products were raised at Conab, effective as of September 1, 2014; for the payment of the products of family agriculture, being for kale $\mathrm{R} \$ 3.74$; 
coriander $\mathrm{R} \$ 3.03$; lettuce $\mathrm{R} \$ 5.05$ and chives $\mathrm{R} \$$ 2.64 .

Depreciation was calculated based on the linear, method by the formula: $\mathrm{D}=(\mathrm{Iv}-\mathrm{Rv}) /(\mathrm{N} . \mathrm{H})$. Where: $\mathrm{D}=$ Depreciation ( $\mathrm{R} \$$ / hours), Iv = initial value (new), $\mathrm{Rv}=$ residual value; $\mathrm{N}=$ useful life (years) and $\mathrm{H}=$ hours of use year. Residual value for the tractor was considered equal to $20 \%$ of the value new, after 10 years of use, while for the implements the residual value was considered equal to 0 .

The gross revenue (GR) was obtained by the product between the production and the price, being that and in the bicultive was carried out the individual calculation for each culture and then the sum of the values.

Net revenue (NR) was calculated by the difference between gross production revenue and total operating cost (TOC) in all cropping systems and estimated for one hectare one area. The calculation of the rate of return (RR) was obtained by the ratio of gross revenue to total operational costs of each treatment. For the evaluation of the profitability index (PI), the ratio between net and gross revenue was used, with values expressed as a percentage.

\section{RESULTS AND DISCUSSION}

By the technical coefficients (Table 2), it was verified that the total operational costs of implantation kale (Brassica oleracea var. acephala DC.), coriander (Coriandrum sativum L.), lettuce (Lactuca sativa L.), and chives (Allium schoenoprasum L.) in monoculture were $\mathrm{R} \$$ 8,308.79; R\$ 8,009.52; R\$ 9,285.18 and 9,918.36 $\mathrm{ha}^{-1}$, respectively.

Table 2. Technical coefficients and total operational cost for production per hectare of kale (T1), coriander (T2), lettuce (T3), and chives (T4), in monoculture.

\begin{tabular}{|c|c|c|c|c|c|c|c|c|c|c|c|c|}
\hline \multirow{3}{*}{$\begin{array}{c}\text { Operation } \\
\text { Type }\end{array}$} & \multicolumn{3}{|c|}{ Kale (T1) } & \multicolumn{3}{|c|}{ Coriander (T2) } & \multicolumn{3}{|c|}{ Lettuce (T3) } & \multicolumn{3}{|c|}{ Chives (T4) } \\
\hline & $\mathrm{CLM}^{1}$ & $\begin{array}{l}\mathrm{SL} \\
\mathrm{T}^{2}\end{array}$ & $\mathrm{~T}+\mathrm{I}^{3}$ & CLM & $\begin{array}{c}\mathrm{SL} \\
\mathrm{T}\end{array}$ & $\mathrm{T}+\mathrm{I}$ & CLM & $\begin{array}{c}\mathrm{SL} \\
\mathrm{T}\end{array}$ & $\mathrm{T}+\mathrm{I}$ & CLM & $\begin{array}{c}\mathrm{SL} \\
\mathrm{T}\end{array}$ & $\mathrm{T}+\mathrm{I}$ \\
\hline & \multicolumn{12}{|c|}{ Technical Coefficients (hours ha ${ }^{-1}$ ) } \\
\hline $\begin{array}{l}\text { Cleaning the } \\
\text { Surface }\end{array}$ & 16.28 & - & 16.28 & 16.28 & - & 16.28 & 16.28 & - & 16.28 & 16.28 & - & 16.28 \\
\hline Tilling & - & 3.88 & 3.88 & - & 3.88 & 3.88 & - & 3.88 & 3.88 & - & 3.88 & 3.88 \\
\hline Harrow & - & 1.76 & 1.76 & - & 1.76 & 1.76 & & 1.76 & 1.76 & - & 1.76 & 1.76 \\
\hline Soil bed & 504.0 & - & $\begin{array}{c}500.0 \\
0\end{array}$ & 504.00 & - & $\begin{array}{c}500.0 \\
0\end{array}$ & 504.00 & - & $\begin{array}{c}500.0 \\
0\end{array}$ & 504.00 & - & $\begin{array}{c}500.0 \\
0\end{array}$ \\
\hline $\begin{array}{l}\text { Seedling } \\
\text { production }\end{array}$ & 13.1 & - & - & - & - & - & 69.4 & - & - & 59.1 & - & - \\
\hline Manual seeding & - & - & - & 38.45 & - & - & - & - & - & - & - & - \\
\hline Transplant & 16.8 & - & - & - & - & - & 157.5 & - & - & 189.0 & - & - \\
\hline $\begin{array}{c}\text { Manual } \\
\text { weeding }\end{array}$ & 236.8 & & & 140.6 & & & 150.00 & & & 280.6 & - & - \\
\hline Fertilizing & 23.94 & - & - & 44.7 & - & - & 106.7 & - & - & 72.71 & - & - \\
\hline $\begin{array}{l}\text { Application of } \\
\text { pesticides }\end{array}$ & 14.88 & - & 14.88 & 14.88 & - & 14.88 & 14.88 & - & 14.88 & 14.88 & - & 14.88 \\
\hline Irrigation & 10.00 & - & 30.00 & 5 & - & 15.00 & 5.00 & - & 15.00 & 10.00 & - & 30.00 \\
\hline $\begin{array}{l}\text { Harvest and } \\
\text { postharvest }\end{array}$ & 451.25 & - & - & 575.00 & - & - & 581.25 & - & - & 496.65 & - & - \\
\hline Total & $1,287.5$ & 5.64 & 566.8 & $\begin{array}{c}1,338.9 \\
1 \\
\end{array}$ & 5.64 & 551.8 & $1,605.1$ & 5.64 & 551.8 & $1,643.22$ & 5.64 & 566.8 \\
\hline Cost $\left(\mathrm{R} \$ \mathrm{ha}^{-1}\right)$ & $\begin{array}{c}5,212.6 \\
1\end{array}$ & $\begin{array}{c}25.1 \\
3\end{array}$ & $\begin{array}{c}225.2 \\
9\end{array}$ & $\begin{array}{c}5 \\
422.59 \\
\end{array}$ & $\begin{array}{c}25.1 \\
3\end{array}$ & $\begin{array}{c}201.9 \\
7\end{array}$ & $6,500.36$ & 25.13 & $\begin{array}{c}201.9 \\
7\end{array}$ & $6,655.12$ & $\begin{array}{c}25.1 \\
3\end{array}$ & $\begin{array}{c}213.5 \\
9\end{array}$ \\
\hline Inputs & Qty. & \multicolumn{2}{|c|}{ Value (R\$) } & Qty. & \multicolumn{2}{|c|}{ Value (R\$) } & Qty. & \multicolumn{2}{|c|}{ Value (R\$) } & Qty. & \multicolumn{2}{|c|}{ Value (R\$) } \\
\hline Urea & $0.26 \mathrm{t}$ & \multicolumn{2}{|c|}{1028.20} & $0.15 \mathrm{t}$ & \multicolumn{2}{|c|}{603.34} & $0.15 \mathrm{t}$ & \multicolumn{2}{|c|}{603.34} & $0.15 \mathrm{t}$ & \multicolumn{2}{|c|}{603.34} \\
\hline $\begin{array}{c}\text { Simple } \\
\text { superphosphate }\end{array}$ & $0.22 \mathrm{t}$ & \multicolumn{2}{|c|}{580.80} & $0.33 \mathrm{t}$ & \multicolumn{2}{|c|}{871.20} & $0.33 \mathrm{t}$ & \multicolumn{2}{|c|}{871.20} & $0.33 \mathrm{t}$ & \multicolumn{2}{|c|}{871.20} \\
\hline
\end{tabular}




\begin{tabular}{ccccccccc}
$\begin{array}{c}\text { Potassium } \\
\text { chloride }\end{array}$ & $0.06 \mathrm{t}$ & 390.00 & $0.05 \mathrm{t}$ & 300 & $0.05 \mathrm{t}$ & 300 & $0.05 \mathrm{t}$ & 300 \\
Substrate & $0.18 \mathrm{t}$ & 78.48 & - & - & $0.40 \mathrm{t}$ & 177.67 & 0.50 & 221.27 \\
Herbicide & $5.00 \mathrm{~L}$ & 95.00 & $5.00 \mathrm{~L}$ & 95.00 & $5.00 \mathrm{~L}$ & 95.00 & $5.00 \mathrm{~L}$ & 95.00 \\
Seeds & $1.5 \mathrm{~kg}$ & 366.00 & 15.30 & 275.40 & $1.19 \mathrm{~kg}$ & 29.75 & $5.00 \mathrm{~kg}$ & 42.00 \\
Insecticide & - & 75.00 & - & 75.00 & - & 75.00 & - & 75.00 \\
\hline Costs & & & & $\mathrm{R} \$$ ha $^{-1}$ & & $2,335.31$ \\
\hline Inputs & $2,613.48$ & & $2,219.94$ & & $2,151.96$ & $6,893.83$ \\
Operations & $5,463.03$ & & $5,649.69$ & & $6,727.47$ & 689.21 \\
Depreciation & 232.28 & & 139.89 & & 405.75 & $9,879.43$ & $9,229.14$ \\
Actual operations ${ }^{4}$ & $8,076.51$ & & $7,869.63$ & & $9,285.18$ & $9,918.36$ \\
\hline Total operating cost & 8,30879 & & $8,009.52$ & &
\end{tabular}

${ }^{1}$ Common labor (manually); ${ }^{2}$ Specialized labor (tractor driver); ${ }^{3}$ costs with tractor and implements in operations; ${ }^{4}$ effective operating cost $=$ cost of operations + cost of inputs .

The highest TOC in monoculture was observed in chives. This behavior occurred due to the higher demand for operations (R \$ 6,893.83 ha${ }^{1}$ ), plus the need for four manual weeding for the cultivation of chives and, consequently, the higher depreciation value of the materials ( $\mathrm{R} \$ 689.21 \mathrm{ha}^{-1}$ ). On the other hand, it was the monoculture of the coriander that obtained the lowest TOC average, due to the lower effective operating cost $(\mathrm{R} \$ 7,869.63$ $\mathrm{ha}^{-1}$ ). In Pombal, PB, working with lettuce and coriander in intercropping under different types of fertilizers, the authors obtained TOCs ranging from $\mathrm{R} \$ 9,137.60$ to $\mathrm{R} \$ 6,584.89$. The highest TOC was in mineral fertilization, with an increase regarding operations specifically in cover fertilization and the lowest in green fertilization, since it had a lower cost with inputs (LACERDA et al., 2017).

For the bicultives of kale with coriander (T5), with lettuce (T6), and with chives (T7) the TOCs were estimated at $\mathrm{R} \$ 10,921.64 ; 12,380.15$; $12,421.40 \mathrm{ha}^{-1}$, respectively. This is justified by the need for more inputs demanded by these crops, such as the substrate, for example (Table 3). In the lettuce and arugula intercropping also noted higher demand for agricultural inputs and labor (NASCIMENTO et al., 2018).

The bicultive $\mathrm{T} 5$ showed a reduction of $12 \%$ of TOC concerning the bicultive T7, which presented the highest TOC (R $\left.\$ 12,421.40 \mathrm{ha}^{-1}\right)$. The main reason for the lower cost of T5 compared to T7 is the lower expenses with operations, which totaled R \$ 7,440.35 ha ${ }^{-1}$ (T5) and R \$ 8,270.32 ha (T7).

TOCs for the production of crops in the T8, T9, T10 and T11 polyculture systems were R\$ 14,711.68; 11,967.66; 11,337.60 and 10,348.21, respectively (Table 4). In contrast, to a polyculture of kale, coriander, lettuce, and chives (K, Co, L e Ch) (T8), the polyculture of kale, coriander, and chives (T11) was the most economical, between intercropping systems, presenting a TOC of $\mathrm{R} \$$ $10,348.21 \mathrm{ha}^{-1}$, in this treatment the expense with the effective operations were lower in $29.6 \%$ than the polyculture T8. In a word, evaluating the agronomic performance of the sesame bean intercropping was reported as an increase in yield per unit area, promoting the efficient use of land, labor, and agricultural inputs (BHATTI et al., 2013).

Table 3. Technical coefficients and total operational cost to produce 1 hectare of kale and coriander (T5), kale and Lettuce (T6), and kale and chives (T7), in bicultive.

\begin{tabular}{|c|c|c|c|c|c|c|c|c|c|}
\hline \multirow[t]{2}{*}{ Operation } & \multicolumn{3}{|c|}{ Kale and coriander (T5) } & \multicolumn{3}{|c|}{ Kale and Lettuce (T6) } & \multicolumn{3}{|c|}{ Kale and Chive (T7) } \\
\hline & $\mathrm{CLM}^{1}$ & $\mathrm{SLT}^{2}$ & $\mathrm{~T}+\mathrm{I}^{3}$ & CLM & SLT & $\mathrm{T}+\mathrm{I}$ & CLM & SLT & $\mathrm{T}+\mathrm{I}$ \\
\hline Type & \multicolumn{9}{|c|}{ Technical Coefficients (hours ha ${ }^{-1}$ ) } \\
\hline $\begin{array}{l}\text { Cleaning the } \\
\text { Surface }\end{array}$ & 16.28 & - & 16.28 & 16.28 & - & 16.28 & 16.28 & - & 16.28 \\
\hline Tilling & - & 3.88 & 3.88 & - & 3.88 & 3.88 & - & 3.88 & 3.88 \\
\hline Harrow & - & 1.76 & 1.76 & - & 1.76 & 1.76 & - & 1.76 & 1.76 \\
\hline Soil bed & 509.00 & - & 500.00 & 509.00 & - & 500.00 & 509.00 & - & 500.00 \\
\hline Seedling & 13.1 & - & - & 82.5 & - & - & 72.2 & - & \\
\hline
\end{tabular}




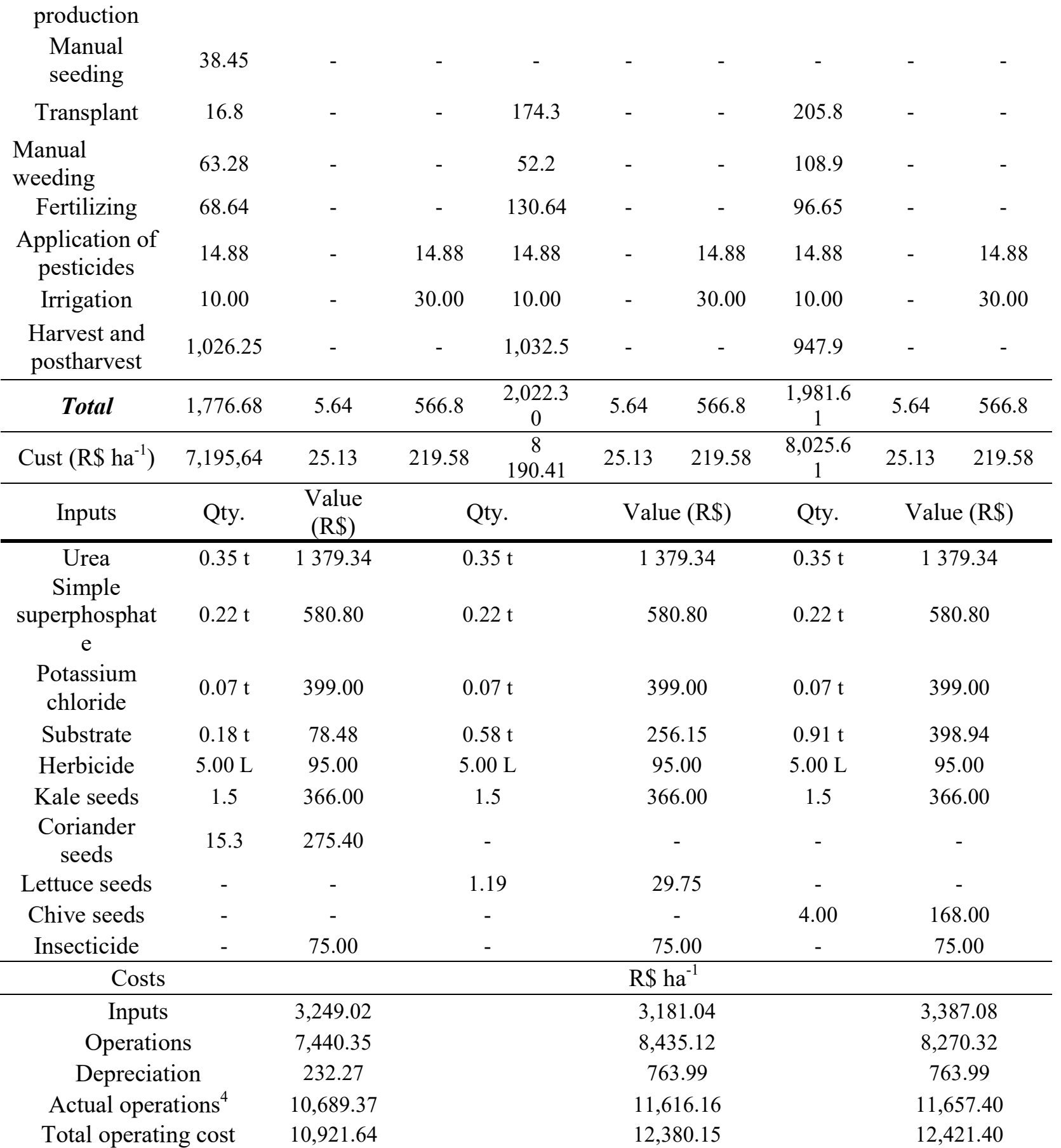

${ }^{1}$ Common labor (manually); ${ }^{2}$ Specialized labor (tractor driver); ${ }^{3}$ costs with tractor and implements in operations; ${ }^{4}$ effective operating cost $=$ cost of operations + cost of inputs .

In the COTs of monocultures (Table 2), with operations R \$ 5,463.03 ha ${ }^{-1}(65.7 \%)$ was spent for kale and R \$ 5,649.69 ha ${ }^{-1}(70.5 \%) ; \mathrm{R} \$ 6,727.47$ $\mathrm{ha}^{-1}(72.4 \%)$ and $\mathrm{R} \$ 6,893.83 \mathrm{ha}^{-1}(69.5 \%)$, for coriander, lettuce and chives, respectively. In the operations performed, which demanded common labor, their values represented $95.4 \%, 95.9 \%, 96.6 \%$ and $96.53 \%$ of the cost for kale, coriander, lettuce, and chives, respectively.
Studying the economic viability of lettuce in intercropping with arugula was observed that the item with the greatest impact on the cost of operations was the common labor, specifically the activities related to the harvest and post-harvest that consumed around 71 and $69,6 \%$, respectively (NASCIMENTO et al., 2018). 
Economic study...

LACERDA, R. R. A. et al.

Table 4. Technical coefficients and total operational cost (TOC) of kale, coriander, lettuce, and chives production (T8); kale, coriander, and lettuce (T9); kale, lettuce, and chives (T10); kale, coriander, and chives (T11), in polyculture.

\begin{tabular}{|c|c|c|c|c|c|c|c|c|c|c|c|c|}
\hline \multirow{3}{*}{$\begin{array}{c}\text { Operation } \\
\text { Type }\end{array}$} & \multicolumn{3}{|c|}{$\begin{array}{c}\mathrm{K}+\mathrm{Co}+\mathrm{L}+\mathrm{Ch} \\
(\mathrm{T} 8)\end{array}$} & \multicolumn{3}{|c|}{$\mathrm{K}+\mathrm{Co}+\mathrm{L}(\mathrm{T} 9)$} & \multicolumn{3}{|c|}{$\mathrm{K}+\mathrm{L}+\mathrm{Ch}(\mathrm{T} 10)$} & \multicolumn{3}{|c|}{$\mathrm{K}+\mathrm{Co}+\mathrm{Ch}(\mathrm{T} 11)$} \\
\hline & $\mathrm{CLM}^{1}$ & $\begin{array}{l}\mathrm{SL} \\
\mathrm{T}^{2}\end{array}$ & $\mathrm{~T}+\mathrm{I}^{3}$ & CLM & $\begin{array}{c}\mathrm{SL} \\
\mathrm{T}\end{array}$ & $\mathrm{T}+\mathrm{I}$ & CLM & $\begin{array}{c}\mathrm{SL} \\
\mathrm{T}\end{array}$ & $\mathrm{T}+\mathrm{I}$ & CLM & $\begin{array}{c}\text { SL } \\
\mathrm{T}\end{array}$ & $\mathrm{T}+\mathrm{I}$ \\
\hline & \multicolumn{12}{|c|}{ Technical Coefficients (hours ha $^{-1}$ ) } \\
\hline $\begin{array}{l}\text { Cleaning the } \\
\text { Surface }\end{array}$ & 16.28 & - & 16.28 & 16.28 & - & 16.28 & 16.28 & - & 16.28 & 16.28 & - & 16.28 \\
\hline Tilling & - & 3.88 & 3.88 & - & $\begin{array}{c}3.8 \\
8\end{array}$ & 3.88 & - & $\begin{array}{c}3.8 \\
8\end{array}$ & 3.88 & - & 3.88 & 3.88 \\
\hline Harrow & - & 1.76 & 1.76 & - & $\begin{array}{c}1.7 \\
6\end{array}$ & 1.76 & - & $\begin{array}{c}1.7 \\
6\end{array}$ & 1.76 & & 1.76 & 1.76 \\
\hline Soil bed & 511.0 & - & 500.0 & 509.0 & & 500.0 & 509.00 & - & 500.0 & 509.0 & & 500.0 \\
\hline $\begin{array}{l}\text { Seedling } \\
\text { production }\end{array}$ & 77.3 & - & - & 47.8 & - & - & 77.3 & - & - & 42.6 & - & - \\
\hline Transplant & 190.05 & - & - & 95.55 & - & - & 190.05 & - & - & 111.3 & - & - \\
\hline Manual seeding & 19.23 & - & - & 19.23 & - & - & - & - & - & 19.23 & - & - \\
\hline $\begin{array}{l}\text { Manual } \\
\text { weeding }\end{array}$ & 41.3 & - & - & 39.1 & - & - & 81.0 & - & - & 87.9 & - & - \\
\hline Fertilizing & 135.99 & - & - & 99.64 & - & - & 113.64 & - & - & 82.64 & - & - \\
\hline $\begin{array}{l}\text { Application of } \\
\text { pesticides }\end{array}$ & 14.88 & - & 14.88 & 14.88 & - & 14.88 & 14.88 & - & 14.88 & 14.88 & - & 14.88 \\
\hline Irrigation & 10.00 & - & 30.00 & 10.00 & - & 30.00 & 10.00 & - & 30.00 & 10.00 & - & 30.00 \\
\hline $\begin{array}{l}\text { Harvest and } \\
\text { postharvest }\end{array}$ & $1,277.6$ & - & - & $1,029.5$ & - & - & 990.1 & - & - & 987.00 & - & - \\
\hline Total & $\begin{array}{c}2,293.6 \\
3\end{array}$ & 5.64 & 566.8 & $1,880.83$ & $\begin{array}{c}5.6 \\
4\end{array}$ & 566.8 & $2,002.25$ & $\begin{array}{c}5.6 \\
4\end{array}$ & 566.8 & $1,880.83$ & 5.64 & 566.8 \\
\hline Cust $\left(\mathrm{R} \$ \mathrm{ha}^{-1}\right)$ & $\begin{array}{c}9,289.3 \\
1 \\
\end{array}$ & 25.1 & $\begin{array}{c}219.5 \\
8 \\
\end{array}$ & 7617.45 & $\begin{array}{c}25 . \\
1 \\
\end{array}$ & $\begin{array}{c}219.5 \\
8 \\
\end{array}$ & $8,109.20$ & $\begin{array}{c}25 . \\
1 \\
\end{array}$ & $\begin{array}{c}219.5 \\
8 \\
\end{array}$ & $7,617.45$ & $\begin{array}{c}25.1 \\
3 \\
\end{array}$ & $\begin{array}{c}219.5 \\
8 \\
\end{array}$ \\
\hline Inputs & Qty. & \multicolumn{2}{|c|}{ Valor (R\$) } & Qty. & \multicolumn{2}{|c|}{ Valor (R\$) } & Qty. & \multicolumn{2}{|c|}{ Valor (R\$) } & Qty. & \multicolumn{2}{|c|}{ Valor $(\mathrm{R} \$)$} \\
\hline Urea & $0.53 \mathrm{t}$ & \multicolumn{2}{|c|}{$2,056.40$} & 0.44 & \multicolumn{2}{|c|}{$1,726.60$} & 0.44 & \multicolumn{2}{|c|}{$1,726.60$} & 0.44 & \multicolumn{2}{|c|}{$1,726.60$} \\
\hline $\begin{array}{c}\text { Simple } \\
\text { superphosphate }\end{array}$ & $0.22 \mathrm{t}$ & \multicolumn{2}{|c|}{580.80} & 0.22 & \multicolumn{2}{|c|}{580.80} & 0.22 & \multicolumn{2}{|c|}{580.80} & 0.22 & \multicolumn{2}{|c|}{580.80} \\
\hline $\begin{array}{l}\text { Potassium } \\
\text { chloride }\end{array}$ & 0.07 & \multicolumn{2}{|c|}{399.00} & 0.07 & \multicolumn{2}{|c|}{399.00} & 0.07 & \multicolumn{2}{|c|}{399.00} & 0.07 & \multicolumn{2}{|c|}{399.00} \\
\hline Substrate & $0.73 \mathrm{t}$ & \multicolumn{2}{|c|}{318.28} & 0.49 & \multicolumn{2}{|c|}{212.55} & 0.73 & \multicolumn{2}{|c|}{318.28} & 0.53 & \multicolumn{2}{|c|}{229.45} \\
\hline Herbicide & $5.00 \mathrm{~L}$ & 95 & .00 & $5.00 \mathrm{~L}$ & & .00 & $5.00 \mathrm{~L}$ & & .00 & $5.00 \mathrm{~L}$ & & .00 \\
\hline Kale seeds & 1.5 & 366 & 5.00 & 1.5 & & 6.00 & 1.5 & & 6.00 & 1.5 & & 6.00 \\
\hline Coriander seeds & 7.65 & 13 & 7.7 & 7.65 & & 7.7 & - & & - & 7.65 & & 7.7 \\
\hline Lettuce seeds & 0.59 & 14 & .75 & 0.59 & & .75 & 0.59 & & .75 & - & & - \\
\hline Chive seeds & 2.5 & 105 & .00 & - & & - & 2.5 & & 5.00 & 2.5 & & 5.00 \\
\hline Insecticide & - & 75 & .00 & - & & .00 & - & & .00 & - & & .00 \\
\hline Costs & & & & & & & $\mathrm{R} \$ \mathrm{ha}^{-1}$ & & & & & \\
\hline Inputs & & 4,14 & 7.93 & & 3,60 & 7.40 & & 3,68 & 30.43 & & 3,7 & 14.55 \\
\hline Operations & & 9,53 & 4.02 & & 7,86 & 2.16 & & 8,3 & 3.92 & & & 52.16 \\
\hline Depreciatio & & 1,02 & 9.73 & & & 8.10 & & 1,02 & 9.73 & & & 8.10 \\
\hline Actual operatic & ions ${ }^{4}$ & 13,6 & 81.95 & & 11,4 & 69.56 & & 10,3 & 07.75 & & 9,8 & 50.10 \\
\hline Total operating & $\cos t$ & 14,7 & 11.68 & & 11,9 & 67.66 & & 11,3 & 37.60 & & 10,3 & 48.21 \\
\hline
\end{tabular}

${ }^{1}$ Common labor (manually); ${ }^{2}$ Specialized labor (tractor driver); ${ }^{3}$ costs with tractor and implements in operations; ${ }^{4}$ effective operating cost $=$ cost of operations + cost of inputs. 
Of these, the operations that added the largest hand common labor force were: $38.9 \%$ (kale), 37.4\% (coriander), 31.2\% (lettuce), and $30.5 \%$ (chives), followed by harvesting operations and postharvest operations, transplanting of seedlings and weeding. In this case, in productive areas, re looking for techniques that lead to a significant reduction in the use of common labor, through the technification of some stages of the production process, such as mechanization of the stages of Soil bed, automation in the formation and transplanting of seedlings, as well as postharvest stages.

Among the bicultives (Table 3), it was found that for each TOC, operating costs had of R\$ 7,440.35 ha h $^{-1}$ (68.1\%); 8,435.12 $\mathrm{ha}^{-1}$ (68.2\%); $8,270.35 \mathrm{ha}^{-1}(66.6 \%)$ and with depreciation the cost was R\$ $232.27 \mathrm{ha}^{-1}(2.1 \%) ; 763.99 \mathrm{ha}^{-1}(6.1 \%)$ and $763.99 \mathrm{ha}^{-1}(6.1 \%)$. Regardless of the cultivation system employed, the operations with common manpower account for the highest expenses in relation to the cost of operations, with $96.7 \%$ for kale and coriander, $66.1 \%$ for kale and lettuce, and $97.0 \%$ for kale and chives (Table 3). With the highest expenditure of hours with the Soil bed activities, ground cleaner, and postharvest.

Assessing the economic viability of the lettuce-tomato intercropping was reported that the common labor was the most representative item in the increase in the cost of TOC, mainly due to the requirement in operations manual harvest and postharvest (CECÍLIO FILHO et al., 2010).

Despite the high hand cost of labor, it should be emphasized that this is an important factor in framing it in a sustainable system, by contributing to the social aspect by keeping workers in the field, reducing the exodus. In the composition of TOC, during all bicultive systems, the effective operating costs represented $97.8 \%$ for $\mathrm{T} 5 ; 93.2 \%$ for $\mathrm{T} 6$, and $93.8 \%$ for $\mathrm{T} 7$ with a depreciation of $2.1 ; 6.2$, and $6.2 \%$, respectively.

In the intercropping of the lettuce with coriander was observed an intense contribution of purchase of inputs in the TOC (LACERDA et al., 2017).

Of the TOCs presented for polycultures (Table 4), it can be observed that, from these, operating expenses were R \$9,534.02 $\mathrm{ha}^{-1}(64.8 \%)$ for T8; 7,862.16 ha ${ }^{-1}(65.7 \%)$ for T9; 8,353.92 ha $(73.7 \%)$ for $\mathrm{T} 10$ and $7,862.16 \mathrm{ha}^{-1}(75.9 \%)$ for T11, these values representing the highest costs of producing one hectare with these cropping systems.

The operations with the highest costs in polyculture (Table 4) were those that demanded the largest labor, are Soil bed, harvest, and postharvest, which together totaled $75.5 \% ; 78.8 \% ; 72.2 \% ; 76.6 \%$ for the T8, T9, T10, and T11 polycultures, respectively.

The highest operating expenses were recorded in the polyculture (T8), with 9,534.02 ha', superior to the bicultives (T5, T6, and T7) and to the monoculture of the kale that obtained the lowest value with $5,463.03 \mathrm{ha}^{-1}$. For the polycultures (T10) and (T11), the values were lower than those of the kale bicultive with lettuce (T6) and of the kale with the chives (T7). The TOC had similar behavior, indicating that the above bicultives increase expenses when compared to polycultures (Tables 3 and 4).

Also, about the harvesting and postharvest operations, the costs for these operations remained the same for the systems in bicultive and monoculture, differentiating only in polyculture, since in polyculture the number of plants was divided into half. Nevertheless, in polyculture, the requirement for common and similar labor to the bicultive of the kale with the cultures, except for the polyculture (T8), that when compared with the other polycultures varied approximately from 12 to $18 \%$.

Regarding the expenses with inputs in monocultures, Table 2 points that these totaled $\mathrm{R} \$$ 2,613.48; 2,219.94; 2,151,96 and 2,335.31 ha $\mathrm{ha}^{-1}$ for kale (T1), coriander (T2), lettuce (T3), and chives (T4). The component that most burdened was the cost of production inputs in monoculture, spent on fertilizers, with $90 \%$ for $\mathrm{T} 1,79.9 \%$ for $\mathrm{T} 2,82.4 \%$ for $\mathrm{T} 3$, and $75.9 \%$ for $\mathrm{T} 4$, in addition to the expenditure with insecticide, substrate, and herbicide. Depreciation expenses were $2.7 \% \mathrm{~T} 1$; $1.7 \% \mathrm{~T} 2,4.3 \% \mathrm{~T} 3$, and $6.9 \% \mathrm{~T} 4$ of the $\mathrm{TOC}$ of the cultures.

It is observed Table 2 shows that each respective TOC was composed of a cost of R \$ 3,249.02 (29.7\%); 3,106.04 (25.1\%); 3,387.08 ha ${ }^{-1}$ $(27.3 \%) \mathrm{ha}^{-1}$ relative to inputs.

Observing the TOCs of polycultures, about input costs, these represented $28.2 \%$ for kale, coriander, lettuce and chives (T8); $30.1 \%$ for kale, coriander and lettuce (T9); $32.5 \%$ for kale, lettuce and chives (T10) and $35.8 \%$ for kale, coriander and chives (T11). The component that increased the most was also the fertilizers, with $73.2 \% ; 75.0 \%$; $73,5 \% ; 72,9 \%$ for $\mathrm{T} 1, \mathrm{~T} 2, \mathrm{~T} 3$, and $\mathrm{T} 4$, respectively, followed by seeds, herbicide, substrate, and insecticides (Table 4).

The treatments that presented the highest expenses with inputs were in polyculture, where T8 presented the highest expense with $\mathrm{R} \$ 4,147.93 \mathrm{ha}^{-}$ ${ }^{1}$, and $\mathrm{T} 9$ contrasted with the smaller value, totaling $\mathrm{R} \$ 3,607.40 \mathrm{ha}^{-1}$. For the treatments in bicultive, we 
have that the $\mathrm{T} 7$ presented greater value with $\mathrm{R} \$$ $3,387.08 \mathrm{ha}^{-1}$. In turn, the T6 had the lowest value of $\mathrm{R} \$ 3,181.04 \mathrm{ha}^{-1}$. In the monoculture to produce one hectare of kale, $\mathrm{R} \$ 2,613.48$ is spent on inputs, for coriander, lettuce and spring onions, $\mathrm{R} \$$ $2,219.95 ; 2,151.96 ; 2,335.31$, respectively.

These results are consistent, that is, for one hectare of kale in polyculture the inputs (fertilization, seeds, and substrate) are used for each crop, understanding that in the system the crops range from three to four. In bicultive and monoculture the number of species decreases to two and one, respectively. The other inputs (herbicide and insecticide) are used equally in all systems.

Regarding the input costs, independent of the cultivation system, the purchase of fertilizers accounts for the highest cost, with values between $12.2 \%$ and $42.4 \%$, followed by the cost of seeds (Table 2). For the treatments T6 and T7, the substrate costs increased between 326.3 and 508.3\% compared to the T5 treatment, due to the non-use of substrate for the coriander culture, implying the less need for inputs in the production stage of seedlings in T5, consequently lower TOC.

Practices, such as phytosanitary treatments, are also optimized in the bicultive, since the jet sprayer application covers the two crops intercalated, not being wasted solution in between crop lines, whereas in the monoculture there would be uncovered soil or presence of weeds. However, it is up to the worker to observe and make applications of products that are recommended for both cultures involved in the intercropping, a requirement that is still characterized as one of the limitations for the intercropping.

The cost with common labor and with fertilizer presented significant increases for the intercropping system. However, it is necessary to consider the lack of dosage recommendation and mode of application for the system of intercropped vegetable cultivation, although previous studies and price surveys may be fundamental to minimize these expenses. A study has verified the economics of TOC in intercropping cultivation of lettuce and tomato, in relation to addition their TOCs of monocultures, the greater cost was with labor for harvesting, followed by side dressing and weeding, which once they were made in tomato cultivated, in two of these, there was no need to be repeated for lettuce in the intercropping (CECÍLIO FILHO et al, 2010).

Tables 2, 3, and 4 show that the production costs of the intercropping with kale were higher compared to kale monoculture, with increases of 23.9\% T5: 32.8\% T6 and 33.1\% T7. These increases in TOC can be seen, for example, by comparing the monoculture of the kale with the bicultive T7, where there was an increase in the number of manual practices (seedling transplanting, manual weeding, fertilization) and mechanized (increase in total hours required to transport production) and the use of inputs (higher amounts of fertilizer, due to the different needs of each crop).

This behavior was expected since the cultivation of associated crops promotes additional costs in the production system. Other authors also reported this behavior, mainly about the differences between the costs of labor, transportation, and packaging (SOUZA et al., 2015). Evaluating the viability of coriander, arugula, and carrot cultivars in intercropped were explained that the higher production costs were related to the greater amount of plant material used in the intercropped system in relation to the material used in the monoculture (SILVA et al., 2017). A similar fact to what occurred in the present study.

The gross revenue (GR) from lettuce monoculture (T3) (Table 5) presented the highest value of $\mathrm{R} \$ 174,225.00 \mathrm{ha}^{-1}$, the good price attributed, and the higher production contributed to the increase in GR. On the other hand, it was observed that in the monoculture of the onion (T4) the lowest value of gross revenue with $\mathrm{R} \$ 44,748.37$ $\mathrm{ha}^{-1}$, this treatment had low productivity in relation to the bicultive T7, besides the low price.

Among the intercropping systems, the highest gross revenues (GR) (Table 4) occurred with bicultive (T6) followed by polyculture (T8) and polyculture (T9), respectively, with values of $\mathrm{R} \$$ $186,207.52 \mathrm{ha}^{-1}, \mathrm{R}$ \& 142,592.03 $\mathrm{ha}^{-1}$ and $142,225.90$ being the result of the good prices and the high productivity of the cultures in the bicultive.

For net revenues (NR), concerning the intercropping systems, the highest value was obtained in the bicultive of kale with lettuce (T6) R $\$ 173,827.37 \mathrm{ha}^{-1}$. It was the bicultive of the kale with chives (T7) that obtained a smaller value $\mathrm{R} \$$ $69,460.85 \mathrm{ha}^{-1}$.

This result is attributed to the better use of the area, taking into account that operations such as soil preparation, spraying, weeding, among others, are carried out jointly, thus reducing production costs. Similar behavior was observed in other tests (NASCIMENTO et al., 2018).

Although 1 hectare of the T8 polyculture and the bicultive $\mathrm{T} 7$ provided higher TOC than 1 hectare in monoculture (Tables 2, 3, and 4), the polycultures and the bicultives were responsible for high revenues, resulting in greater profitability to the producer. Also, greater diversity of products 
obtained in the polyculture and bicultive since in the monoculture would only have a vegetal species, that is, heterogeneity of products to be negotiated in the same property representing a strategy that attracts the buyers to reduce the time and costs with displacement. Corroborating with others experiments, when the authors affirming to have obtained better economic returns in the bicultive, mainly by the greater gross revenue generated in this system, the best yields by the Profitability
Index were observed in lettuce culture when submitted to cattle manure (LACERDA et al., 2017).

The rates of return and profitability index of the polycultures (T8) (9.6 and 89.6\%); (T10) (11.7 and $91.4 \%)$ and (T11) (7.8 and $87.3 \%)$, were higher than their respective monocultures, except lettuce (T3), respectively, $18.7 \%, 94.6 \%$ (Table 5).

Table 5. Productivity (Prod), Efficient land use (EUL), price, gross revenue (GR), total operating cost (TOC), net revenue (NR), rate of return (RR), and profitability index (PI) for the production of 1-hectare kale, coriander, lettuce, and chives, in intercropping systems and monoculture.

\begin{tabular}{|c|c|c|c|c|c|c|c|c|c|}
\hline \multicolumn{2}{|c|}{ Treatments } & $\begin{array}{c}\text { Prod. } \\
\left(\mathrm{kg} \mathrm{ha}^{-1}\right)\end{array}$ & \multirow{2}{*}{$\begin{array}{c}\text { EU } \\
\mathrm{L} \\
1.00\end{array}$} & $\begin{array}{c}\text { Price } \\
\left(\mathrm{R} \$ \mathrm{~kg}^{-1}\right) \\
\end{array}$ & \multicolumn{3}{|c|}{$\begin{array}{c}\text { TOC } \\
\left(\mathrm{R} \$ \mathrm{ha}^{-1}\right)\end{array}$} & $\mathrm{RR}^{3}$ & $\begin{array}{c}\mathrm{PI}^{4} \\
\%\end{array}$ \\
\hline $\mathrm{T} 1$ & Kale & $21,211.00$ & & 3.74 & $79,329.14$ & $8,308.79$ & $71,020.35$ & 9.55 & 89.53 \\
\hline $\mathrm{T} 2$ & Coriander & $17,780.00$ & 1.00 & 3.03 & $53,873.40$ & $8,009.52$ & $45,863.88$ & 6.73 & 85.13 \\
\hline T3 & Lettuce & $34,500.00$ & 1.00 & 5.05 & $174,225.00$ & $9,285.18$ & $164,939.82$ & 18.76 & 94.67 \\
\hline T4 & Chive & $16,950.00$ & 1.00 & 2.64 & $44,748.00$ & $9,458.90$ & $35,289.10$ & 4.73 & 78.86 \\
\hline \multirow{3}{*}{$\mathrm{T} 5$} & Kale & $12,892.50$ & \multirow{3}{*}{1.53} & 3.74 & $48,217.95$ & \multirow{3}{*}{$10,921.64$} & \multirow{3}{*}{$86,864.69$} & \multirow{3}{*}{8.95} & \multirow{3}{*}{88.83} \\
\hline & Coriander & $16,359.20$ & & 3.03 & $49,568.38$ & & & & \\
\hline & Total & $29,251.70$ & & & $97,786.33$ & & & & \\
\hline \multirow{3}{*}{ T6 } & Kale & $9,347.60$ & \multirow{3}{*}{1.32} & 3.74 & $34,960.02$ & \multirow{3}{*}{$12,380.15$} & \multirow{3}{*}{$173,827.37$} & \multirow{3}{*}{15.04} & \multirow{3}{*}{93.35} \\
\hline & Lettuce & $29,950.00$ & & 5.05 & $151,247.50$ & & & & \\
\hline & Total & $39,297.60$ & & & $186,207.52$ & & & & \\
\hline \multirow{3}{*}{$\mathrm{T} 7$} & Kale & $9,236.00$ & \multirow{3}{*}{1.50} & 3.74 & $34,542.64$ & \multirow{3}{*}{$12,403.79$} & \multirow{3}{*}{$69,460.85$} & \multirow{3}{*}{6.60} & \multirow{3}{*}{84.85} \\
\hline & Chive & $17,925.00$ & & 2.64 & $47,322.00$ & & & & \\
\hline & Total & $27,161.00$ & & & $81,864.64$ & & & & \\
\hline \multirow{5}{*}{$\mathrm{T} 8$} & Kale & $8,250.00$ & \multirow{5}{*}{1.57} & 3.74 & $30,855.00$ & \multirow{5}{*}{$14,711.68$} & \multirow{5}{*}{$127,880.35$} & & \\
\hline & Coriander & $7,142.50$ & & 3.03 & $21,641.78$ & & & & \\
\hline & Lettuce & $14,325.00$ & & 5.05 & $72,341.25$ & & & 9.69 & 89.68 \\
\hline & Chive & $6,725.00$ & & 2.64 & $17,754.00$ & & & & \\
\hline & Total & $36,442.50$ & & & $142,592.03$ & & & & \\
\hline & Kale & $11,538.50$ & & 3.74 & $43,153.99$ & & & & \\
\hline ТО & Coriander & $7,009.50$ & & 3.03 & $21,238.79$ & & & & \\
\hline 19 & Lettuce & $15,412.50$ & 1.38 & 5.05 & $77,833.13$ & $11,967.66$ & $130,258.24$ & 11.88 & 91.59 \\
\hline & Total & $33,960.50$ & & & $142,225.90$ & & & & \\
\hline & Kale & $11,632.10$ & & 3.74 & $43,504.05$ & & & & \\
\hline & Lettuce & $14,512.50$ & & 5.05 & $73,288.13$ & & & & \\
\hline T10 & Chives & $6,150.00$ & 1.33 & 2.64 & $16,236.00$ & $11,337.60$ & $121,690.58$ & 11.73 & 91.48 \\
\hline & Total & $32,294.60$ & & & $133,028.18$ & & & & \\
\hline & Kale & $10,016.50$ & & 3.74 & $37,461.71$ & & & & \\
\hline & Coriander & $8,670.00$ & & 3.03 & $26,270.10$ & & & & \\
\hline T11 & Chives & $6,737.20$ & 1.36 & 2.64 & $17,786.21$ & $10,349.21$ & $71,168.81$ & 7.88 & 87.30 \\
\hline & Total & $25,423.70$ & & & $81,518.02$ & & & & \\
\hline
\end{tabular}

${ }^{1} \mathrm{RB}=$ Productions $x$ cost; $2 \mathrm{RL}=\mathrm{RB}-\mathrm{CO} T ; 3 \mathrm{TR}=\overline{\mathrm{RB} / \mathrm{COT} ; 4 \mathrm{IL}=(\mathrm{RB} * 100) / \mathrm{RL}}$.

These results are associated with the fact that polycultures expressed the best values for efficient land use, and thus this agronomic superiority was translated into economic gain, that is, return and profitability of the intercropping systems.

An analysis of the economic viability of the cucumber and lettuce intercropping, it was also 
observed a higher profit in the intercropping system than in the monoculture (REZENDE et al., 2011).

Regarding the economic aspects of Table 5, a significant advantage was observed when comparing the bicultive and polyculture systems with monocultures, where the intercropping systems had higher net revenue, that is, a greater increase in their profitability, in relation to the monoculture, except for lettuce. Highlighting the bicultive of kale with lettuce, with net income of R \$173,827.37 ha ${ }^{-1}$ and the rate of return of $R \$ 15.04$, where high productivity and the price of vegetables made the difference. With this, it emphasizes the efficiency of working with systems in bicultives.

This economic analysis evidences the increase in the income of the intercropping systems, corroborating with the UET values in all the treatments, in agreement with almost all the values of gross and net revenue, which in turn, were superior to their monocultures. It is observed that the monoculture of kale has higher presented productivity, but all the intercropping systems obtained EUL higher than 1.0, demonstrating the viability of 32 to $57 \%$.

These results portray the positive effects of intercropping on vegetable production. According to the authors, observed to EUL values greater than 1.0 represent that the intercropping will favor the growth of the intercropped cultures (CECÍLIO FILHO et al., 2010). This indicates that this cultivation system uses environmental resources more efficiently.

EUL values found in our studies were up to 1.57 in polyculture (T8). Higher values were found to study the agroeconomic viability of an intercropping of coriander, lettuce, and arugula under different spatial arrangements that obtained higher values of up to 1.80 (LIMA et al., 2014). In other words, studying the combinations of coriander and arugula cultivars in biculture intercropped with carrot cultivars was obtained UET of up to 2.97 (SILVA et al., 2017).

The economic viability of the intercropped systems is subject to the standards of cultivation and crop selection, since the intercropped systems, in addition to ensuring greater stability in production, reduce the seasonal risks characteristic of the semiarid region, guaranteeing thus generating adequate income for small farmers (PINTO; PINTO, 2012).

\section{CONCLUSIONS}

The greater economic viability of the intercropped systems was observed bicultives in kale with lettuce and in kale polycultures with coriander and lettuce. With very significant economic indicators. Although the cabbage monoculture showed higher productivity, all the intercropped systems obtained EUL higher than 1.0, showing the viability of 32 to $57 \%$.

RESUMO: O cultivo de hortaliças de maneira mal planejada pode não alcançar os resultados econômicos esperados, pois é uma atividade que exige grande capacidade técnica e administrativa do produtor. O objetivo deste estudo foi avaliar a viabilidade econômica de cultivar couve, alface e cebolinha em consórcio. O experimento foi conduzido no Centro de Ciência e Tecnologia Agroalimentar da Universidade Federal de Campina Grande, no município de Pombal, PB, no período de junho de 2014 a julho de 2015. Foram testados onze tratamentos: quatro policultivos, três bicultivos e quatro monocultivos, em blocos casualizados, com quatro repetições. Foram avaliados: produtividade; custos operacionais totais (COT); receita bruta e líquida; taxa de retorno; índice de lucratividade e uso eficiente da terra (UET). Os valores de COT do consórcio foram calculados com os preços de julho de 2015. Em todos os sistemas estudados, a maior participação foi referente ao custo mão de obra. As maiores receita bruta e líquida foram observadas na couve com alface em bicultivo, a taxa de retorno e rentabilidade índice foram maiores na alface em monocultura. Apesar do aumento nos COT'S dos consórcios em relação às monoculturas, a consorciação mostrou-se economicamente viável em termos de uso eficiente da terra, alcançando valores que indicam uma eficiência no uso da terra de até $50 \%$ a mais em policultivos e bicultivos.

PALAVRA-CHAVE: Allium schoenoprasum L. Brassica oleracea var. acephala DC. Coriandrum sativum L, Lactuca sativa L. Policultivo. 


\section{REFERÊNCIAS}

AZEVEDO, A. M.; ANDRADE JÚNIOR, V. C. D.; FERNANDES, J. S.; PEDROSA, C. E.; VALADARES, N. R.; FERREIRA, M. A.; MARTINS, R. A. Divergência genética e importância de caracteres morfológicos em genótipos de couve. Horticultura Brasileira, Brasília, v. 32, n. 1, p. 48-54, 2014.

http://dx.doi.org/10.1590/S0102-05362014000100008

BATISTA, T. M. V.; BEZERRA NETO, F; SILVA, I. N.; SILVA, M. L.; OLIVEIRA, E. Q.; BARROS JUNIOR, A. P. Agronomic efficiency of the intercropping of arugula with carrot under different population combinations. Revista Caatinga, Mossoró, v. 29, n. 1, p. 76-84, 2016.

http://dx.doi.org/10.1590/1983-21252016v29n109rc

BEZERRA NETO, F.; PORTO, V. C. N.; GOMES, G. E.; CECÍLIO FILHO, A. B; MOREIRA, J. N.

Assessment of agroeconomic indices in polycultures of lettuce, rocket, and carrot through uni and multivariate approaches in semi-arid Brazil. Ecological Indicators, v. 1, n. 14, p. 11-17, 2012.

https://doi.org/10.1016/j.ecolind.2011.07.006

BHATTI, I. H.; AHMAD, R.; JABBAR, A.; NADEEM, M.; KHAN, M. M.; VAINS, W. S. N. Agronomic performance of mash bean as an intercrop in sesame under different planting patterns. Emirates Journal of Food and Agriculture, v. 25, n. 1, p. 52-57, 2013. https://doi.org/10.9755/ejfa.v25i1.15396

BRANCALIÃO, S. R. Avaliação econômica dos sistemas de semeadura direta e convencional na sucessão soja/sorgo na região de Ribeirão Preto. Trabalho de conclusão de curso. (Graduação em Agronomia) Universidade Estadual Paulista, Jaboticabal, 1999.

CARVALHO, L. C.; ESPERANCINI, M. S.; SANTOS, J. Z.; RIBAS, L. C. Análise comparativa de estimativas de custo de produção e rentabilidade entre sojas RR1 E RR2 PRO/Bt1. Energia na Agricultura, Botucatu, v. 31, n. 2, p.186-191, 2016. https://doi.org/10.17224/EnergAgric.2016v31n2

CAVAlCANTI, F. J. A. Recomendações de adubação para o Estado de Pernambuco: $2^{\circ}$ aproximação. Recife: Instituto Agronômico de Pernambuco, 2008, 212p.

CECÍLIO FILHO, A. B.; REZENDE, B. L. A.; COSTA, C. C. Economic analysis of the intercropping of lettuce and tomato in different seasons under protected cultivation. Horticultura Brasileira, Brasília, v. 28, n. 3, p. 326-336, 2010. https://doi.org/10.1590/S0102-05362010000300015.

LACERDA, R. R. A.; COSTA, C. C.; FERREIRA, J. T. A.; PAIVA, G. P. Economic profitability of lettuce cultivation under different cropping systems and types of fertilizers. Revista Verde de Agroecologia e Desenvolvimento Sustentável, Pombal, v.12, n. 5, p. 849-853, 2017.

https://doi.org/10.18378/rvads.v12i5.5586

LIMA, V. I. A.; BEZERRA NETO, F.; SANTOS, E. C.; RODRIGUES, G. S. O.; DE PAULA, V. F. S. Viabilidade agroeconômica do cultivo consorciado de coentro, alface e rúcula sob diferentes arranjos espaciais. Enciclopédia Biosfera, Goiânia, v. 10, n. 18, p. 3060-3065, 2014.

OLIVEIRA, L. A. A.; BEZERRA NETO, F.; SILVA M. L.; OLIVEIRA, O. F. N.; LIMA, J. S. S.; BARROS JÚNIOR, A. P. Viabilidade agronômica de policultivos de rúcula/cenoura/alface sob quantidades de flor-deseda e densidades populacionais. Revista Caatinga, Mossoró, v. 28, n. 4, p. 116-126, 2015. https://doi.org/10.1590/1983-21252015v28n413rc.

MATSUNAGA, M.; BEMELMANS, P. F.; TOLEDO, P. E. N. DE.; DULLEY, R. D.; OKAWA, H.; PEDROSO, I. A. Metodologia de custo de produção utilizada pelo IEA. Agricultura em São Paulo, v. 23, p. 123-139, 1976. Disponível em: http://www.iea.sp.gov.br/out/verTexto.php?codTexto=11566. 
NASCIMENTO, C. S.; CECÍLIO FILHO, A. B.; CORTEZ, J. W.; NASCIMENTO, C. S.; BEZERRA NETO, F.; GRANGEIRO, L. C. Effect of population density of lettuce intercropped with rocket on productivity and land-use efficiency. PLoS ONE, v. 13, n. 4, p. 1-14, 2018. https://doi.org/10.1371/journal.pone.0194756

NOVO, M. D. C.; PRELA-PANTANO, A.; TRANI, P. E.; BLAT, S. Desenvolvimento e produção de genótipos de couve manteiga. Horticultura Brasileira, Brasília, v. 28, n. 3, p. 321-325, 2010. https://doi.org/10.1590/S0102-05362010000300014

PAIVA, L. G.; COSTA, C. C.; CAVAlCANTE, J. A.; LOPES, K. P.; BARBOSA, J. W. S. Modelagem do dossel fotossintético em sistemas consorciados com alface, rúcula, rabanete, coentro e beterraba. Revista Verde de Agroecologia, Pombal, v. 11, n. 4, p. 51-58, 2016. https://doi.org/10.18378/rvads.v11i4.4631

PINTO, C. M.; PINTO, O. R. O. Avaliação da eficiência biológica e habilidade competitiva nos sistemas de consorciação de plantas. Enciclopédia Biosfera, Goiânia, v. 8, n. 14, p. 105-122, 2012. Disponível em: http://www.conhecer.org.br/enciclop/enciclop.htm

REZENDE, B. L. A.; CECÍlIO-FILHO, A. B.; PÔRTO, D. R. DE Q.; PAES, A. B. J.; SILVA, G. S DA; BARBOSA, J. C.; FELTRIM , A. L. Consórcios de alface crespa e pepino em função da população do pepino e época de cultivo. Interciência, v. 35, p. 374-379, 2010. Disponível em: https://www.interciencia.net/wpcontent/uploads/2018/01/374-c-FILHO-6.pdf.

REZENDE, B. L. A.; CECÍlIO FILHO, A. B.; BARROS JUNIOR, A. P.; PORTO, D. R. Q; MARTINS, M. I. E. G. Economic analysis of cucumber and lettuce intercropping under greenhouse in the winter-spring. Anais da Academia Brasileira de Ciências, v. 83, n. 2, p. 705-717, 2011. https://doi.org/10.1590/S000137652011000200028

SEDIYAMA, M. A. N.; SANTOS, I. C.; LIMA, P. C. Cultivo de hortaliças no sistema orgânico. Revista Ceres, viçosa, v. 61, n. 2, p. 829-837, 2014. http://dx.doi.org/10.1590/0034-737X201461000008. ISSN 2177-3491

SOUZA, E. G. F.; BARROS JUNIOR, A. P.; BEZERRA NETO, F.; SILVEIRA, L. M.; LEAL, Y. H.; ALVES, M. J. G. Rentabilidade da rúcula fertilizada com biomassa de flor-de-seda em função da época de cultivo.

Revista Caatinga, Mossoró, v. 28, n. 1, p. 65-77, 2015. Disponível em:

https://periodicos.ufersa.edu.br/index.php/caatinga/article/view/4092

SILVA, J. N.; BEZERRA NETO, F.; LIMA, J. S. S.; RODRIGUES, G. S. O.; BARROS JUNIOR, A. P.; CHAVES, A. P. Combinations of coriander and salad rocket cultivars in bicropping systems intercropped with carrot cultivars. Revista Caatinga, Mossoró, v. 30, n. 1, p. 125-135. 2017. https://doi.org/10.1590/198321252017v30n114rc.

MEAD, R.; WILLEY, R. W. The Concept of a "Land Equivalent Ratio" and Advantages in Yields from Intercropping. Experimental Agriculture, v. 16, n. 3, p. 217-228, 1980.

https://doi.org/10.1017/S0014479700010978 